\title{
Comparative study of storage compound breakdown in germinating seeds of three lupine species
}

\author{
Sławomir Borek $\cdot$ Szymon Kubala \\ Sylwia Kubala $\cdot$ Lech Ratajezak
}

Received: 10 December 2010/Revised: 19 February 2011/Accepted: 14 March 2011/Published online: 30 March 2011

(C) The Author(s) 2011. This article is published with open access at Springerlink.com

\begin{abstract}
Storage lipid and protein breakdown in germinating seeds of yellow (Lupinus luteus L.), white (L. albus L.), and Andean lupine (L. mutabilis Sweet) and regulatory function of sucrose were investigated. Less oil bodies were detected in organs of yellow lupine seeds, whereas the highest content of oil bodies was noticed in the Andean lupine seeds. Mature, air-dried yellow, white and Andean lupine seeds do not contain starch. Starch grains appear the earliest in white lupine seeds during imbibition. Sucrose deficiency in tissues enhances breakdown of storage lipid, protein and temporary starch in cotyledons. In sucrose starved embryo axes of all investigated lupine species, an increased level of vacuolization was noted. Interconnections between catabolism of storage protein and storage lipid in germinating lupine seeds were identified by applying ${ }^{14} \mathrm{C}$-acetate. To assess the importance of key processes in storage lipid breakdown $\mathrm{NaF}$ (inhibitor of glycolysis and gluconeogenesis), $\mathrm{KCN}, \mathrm{NaN}_{3}$ and SHAM (inhibitors of mitochondrial electron transport chain) and MSO (inhibitor of glutamine synthetase) were used. Radioactivity coming from ${ }^{14} \mathrm{C}$-acetate was released as ${ }^{14} \mathrm{CO}_{2}$ but mostly was incorporated into ethanol-soluble fraction of embryo axes and cotyledons. Respiratory inhibitors caused a significant decrease in ${ }^{14} \mathrm{CO}_{2}$ and ethanol fractions in all three lupine species studied. MSO stimulated release of ${ }^{14} \mathrm{CO}_{2}$ and radioactivity of ethanol fractions in yellow lupine organs fed with sucrose, but in Andean lupine MSO enhanced the production of ${ }^{14} \mathrm{CO}_{2}$ and
\end{abstract}

Communicated by M. Hajduch.

S. Borek $(\bowtie) \cdot$ S. Kubala $\cdot$ S. Kubala $\cdot$ L. Ratajczak

Department of Plant Physiology, Adam Mickiewicz University, ul. Umultowska 89, 61-614 Poznań, Poland

e-mail: borek@amu.edu.pl radioactivity of ethanol fractions both in organs fed and not fed with sucrose. Different strategies of storage compound breakdown are proposed, depending on relative proportion in storage protein and lipid content in lupine seeds.

Keywords Carbon flow - Glutamine synthetase · Non-starch seeds $\cdot$ Sucrose $\cdot$ Ultrastructure

$\begin{array}{ll}\text { Abbreviations } \\ \text { ACO } & \text { Aconitase } \\ \text { AS } & \text { Asparagine synthase (glutamine-hydrolysing) } \\ \text { AT } & \text { Aminotransferases } \\ \text { cMDH } & \text { Cytosolic fraction of malate dehydrogenase } \\ \text { CSY } & \text { Citrate synthase } \\ \text { GDH } & \text { Glutamate dehydrogenase } \\ \text { gMDH } & \text { Glyoxysomal fraction of malate dehydrogenase } \\ \text { GOGAT } & \text { Glutamate synthase } \\ \text { GS } & \text { Glutamine synthetase (glutamate-ammonia } \\ & \text { ligase) } \\ \text { ICL } & \text { Isocitrate lyase } \\ \text { IDH } & \text { Isocitrate dehydrogenase } \\ \text { KCN } & \text { Potassium cyanide } \\ \text { MSO } & \text { L-methionine sulfoximine } \\ \text { NaF } & \text { Sodium fluoride } \\ \text { MDH } & \text { Malate dehydrogenase } \\ \text { MLS } & \text { Malate synthase } \\ \text { NaN } & \text { Sodium azide } \\ \text { PEPCK } & \text { Phosphoenolpyruvate carboxykinase } \\ \text { SHAM } & \text { Salicylhydroxamic acid } \\ & \end{array}$

\section{Introduction}

Numerous research studies regarding storage lipid catabolism are conducted on germinating oil-storing seeds or 
Fig. 1 Schematic representation of acetate metabolism and interconnections between lipid and protein breakdown in germinating lupine seeds. $A C O$ aconitase, $A S$ asparagine synthase (glutaminehydrolysing), $A T$ aminotransferases, $c M D H$ cytosolic fraction of malate dehydrogenase participating in glyoxylate cycle, $C S Y$ citrate synthase, $G D H$ glutamate dehydrogenase, $g M D H$ glyoxysomal fraction of malate dehydrogenase participating in fatty acids $\beta$-oxidation, GOGAT glutamate synthase, $G S$ glutamine synthetase (glutamate-ammonia ligase), $I C L$ isocitrate lyase, $I D H$ isocitrate dehydrogenase, $K C N$ potassium cyanide, $M S O{ }_{\mathrm{L}-}$ methionine sulfoximine, $\mathrm{NaF}$ sodium fluoride, $M L S$ malate synthase, $\mathrm{NaN}_{3}$ sodium azide, PEPCK phosphoenolpyruvate carboxykinase, SHAM salicylhydroxamic acid, $\mathrm{X}$ pathways affected by inhibitors

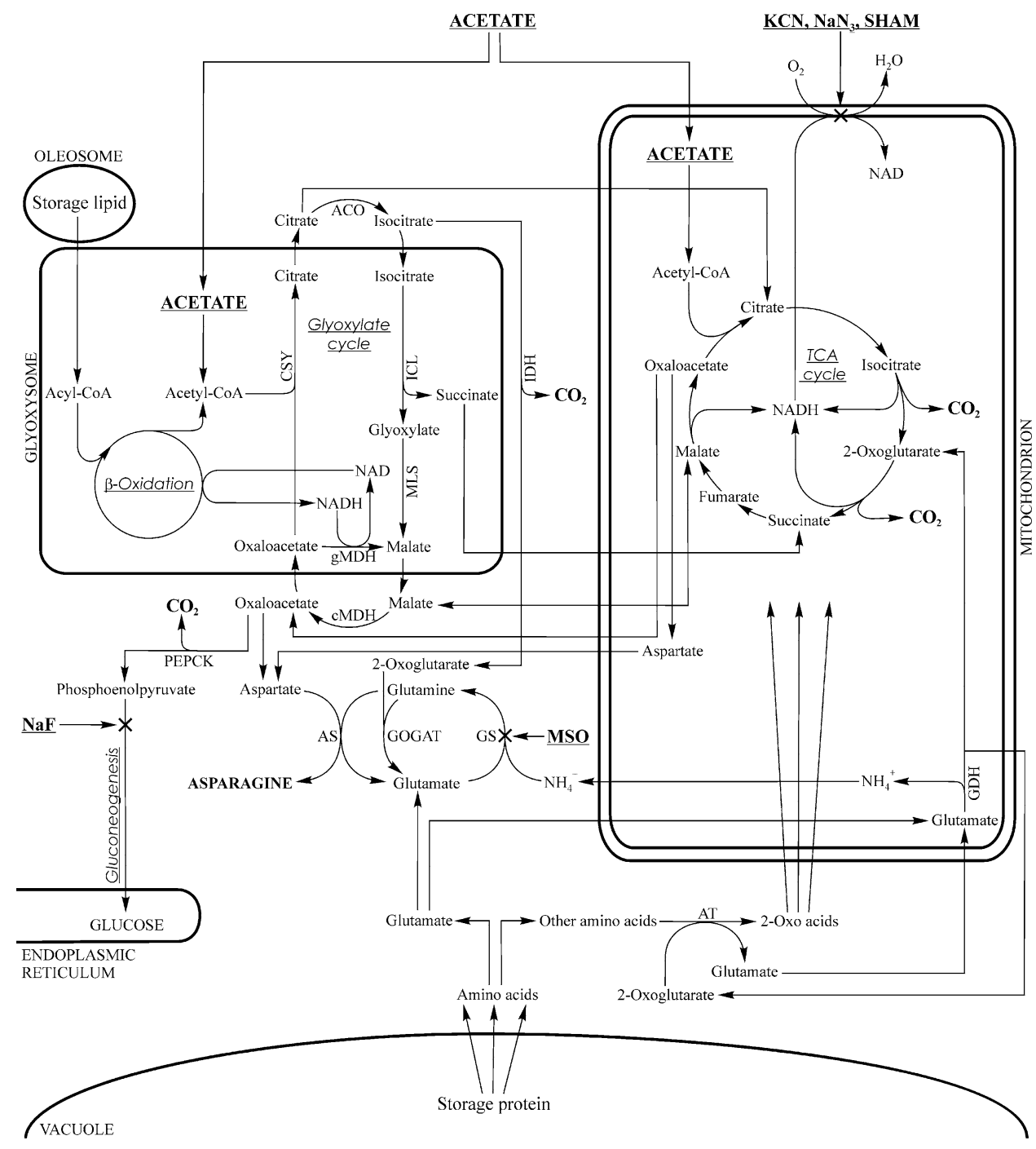

young seedlings. During germination, lipid stored in oleosomes is used both as respiratory substrate and is converted into sugars (Graham 2008). In classical pathway of storage lipid conversion into sugars, the following sequence of metabolic events takes place: lipolysis, fatty acids $\beta$-oxidation, glyoxylate cycle, TCA cycle and gluconeogenesis (Fig. 1). This sequence of events was proposed by Beevers $(1976,1979)$ based on the results of experiments done on young castor bean seedlings and has been confirmed later in other oilseed plants (see reviews of Eastmond and Graham 2001; Penfield et al. 2005, 2006; Graham 2008; Quettier and Eastmond 2009; Kaur et al. 2009). Modifications of the process as described above are known; the examples are Arabidopsis mutants with disruptions in glyoxylate cycle (Eastmond et al. 2000; Cornah et al. 2004; Pracharoenwattana et al. 2005) or flow of lipidderived carbon into developing chloroplast in Arabidopsis (Penfield et al. 2004). Moreover, some data indicate that fatty acid $\beta$-oxidation could be a source of intermediates for phytohormone (indole-3-acetic acid) and the signal molecule (jasmonic acids) synthesis (Baker et al. 2006; Nyathi and Baker 2006; Penfield et al. 2006; Poirier et al. 2006; Kaur et al. 2009).

Glyoxylate cycle is catalyzed by five key enzymes. Two of them, isocitrate lyase (ICL) and malate synthase (MLS), are "hallmark" enzymes for glyoxylate cycle, whereas citrate synthase (CSY), aconitase (ACO) and malate dehydrogenase (MDH) take part in the TCA cycle as well (Graham 2008; Pracharoenwattana and Smith 2008). However, it is known that not all glyoxylate cycle enzymes are located in glyoxysomes. For example, ACO is active in the cytosol and mitochondria but not in glyoxysomes (Courtois-Verniquet and Douce 1993; De Bellis et al. 1994; Hayashi et al. 1995; Eastmond and Graham 2001). MDH is located in glyoxysomes and is active there, but the glyoxysomal fraction of this enzyme does not participate directly in the glyoxylate cycle. Glyoxysomal MDH $(\mathrm{gMDH})$ is involved in $\beta$-oxidation of fatty acids to 
re-oxidize NADH. The activity of the cytosolic MDH $(\mathrm{cMDH})$ fraction is necessary for full operation of the glyoxylate cycle (Pracharoenwattana et al. 2007; Graham 2008; Pracharoenwattana and Smith 2008) (Fig. 1). Location of two enzymes of glyoxylate cycle in cytosol requires export of intermediates from glyoxysomes to cytosol and their subsequent import from cytosol into glyoxysomes. Citrate is exported to cytosol and after conversion to isocitrate by ACO it is imported into glyoxysomes. There, malate is synthesized in two steps catalyzed by ICL and MLS and transported into cytosol. From malate, the oxaloacetate is synthesized by cMDH. After import into glyoxysome, oxaloacetate is converted to citrate by CSY (Graham 2008; Pracharoenwattana and Smith 2008). The substrates and/or products of cytosolic ACO and MDH can be pulled away from the pathway of storage lipid conversion into sucrose and can be a fuel for other extraglyoxysomal processes (Fig. 1). Moreover, in Arabidopsis CSY catalyzes essential step in the respiration of fatty acids that bypass glyoxylate cycle, by translocating citrate into cytosol and channeling it into mitochondria (Pracharoenwattana et al. 2005).

Interplay between carbon and nitrogen metabolism is particularly important in legumes, whose seeds contain large amount of storage protein, but can accumulate large amount of lipid as well. For example, in yellow and Andean lupine seeds, the protein content reaches up to $35 \%$ of dry seed weight (Lehmann and Ratajczak 2008). Accumulation of storage lipid in lupine seeds is at a lower level. Yellow lupine seeds contain about $6 \%$, white lupine $7-14 \%$ and Andean lupine about $20 \%$ oil of dry seed weight (Borek et al. 2009). Mature, air-dried lupine seeds do not contain starch (Borek et al. 2006; Duranti et al. 2008). In germinating lupine seeds, lipid-derived carbon skeletons are used as respiratory substrates and enter pathway of sugars synthesis; however, it was established in experiments with exogenously applied radiolabeled acetate that they are also used in amino acids synthesis (Fig. 1). The high incorporation of carbon atoms coming from storage lipid has been noticed especially in amino acids belonging to the primary amino acid biosynthesis pathway, i.e. asparagine as well as glutamine, glutamate and aspartate (Borek et al. 2003; Borek and Ratajczak 2010). It is postulated that the intermediates of glyoxylate cycle are the source of carbon skeletons for amino acids synthesis (Borek and Ratajczak 2010). In the course of storage protein mobilization during legume seeds germination, large quantities of ammonium are produced. Asparagine, as a temporary storage form of ammonium, is accumulated and in germinating lupine seeds it may reach up to $30 \%$ of seed dry weight (Lehmann and Ratajczak 2008). Ammonium reassimilation is catalyzed by collaborated action of glutamine synthetase (GS) and asparagine synthase (AS) (Lehmann and Ratajczak 2008) (Fig. 1).
In research experiments related to storage lipid catabolism in germinating seeds and young seedlings, exogenously applied acetate is routinely used as the simplest fatty acids. In Arabidopsis seedlings, acetate is used as respiratory substrate but some exogenously applied acetate is directed into glyoxysome where it is activated to acetyl-CoA, and through glyoxylate cycle converted to malate, citrate or succinate. In the next step, it is translocated into mitochondria in the form of four- or sixcarbon organic acids (Eastmond et al. 2000; Hooks et al. 2004; Turner et al. 2005; Kunze et al. 2006; Hooks et al. 2007) (Fig. 1).

To assess the importance of key steps in the pathways of carbon flow from storage lipid to sugars and amino acids in germinating lupine seeds, we used acetate labeled with ${ }^{14} \mathrm{C}$ as well. By applying $\mathrm{NaF}$, we attempted to limit carbon flow through gluconeogenesis (Fig. 1), but $\mathrm{NaF}$ inhibits glycolysis as well. Both processes are inhibited at the enolase (phosphoenolpyruvate hydratase) stage (Miller 1993; Qin et al. 2006). We tested mixture of mitochondrial electron transport chain inhibitors $\left(\mathrm{KCN}, \mathrm{NaN}_{3}\right.$ and SHAM) known to suppress mitochondrial respiration, and MSO as a glutamine synthetase inhibitor which restricts amino acids synthesis (Masclaux-Daubresse et al. 2006) (Fig. 1). Moreover, we investigated the regulatory function of sucrose. We focused our studies on sucrose because besides serving as a respiratory substrate and carbon skeletons donor, sucrose is important regulatory compound which controls plant cell metabolism by modifying the expression of many genes (see reviews of Koch 1996; Rolland et al. 2006; Ramon et al. 2008) among them the genes encoding for the enzymes involved in lipid and protein catabolism. For example, sugar starvation enhances expression and activity of MLS and ICL (Graham et al. 1994) and glutamate dehydrogenase (GDH) (Lehmann et al. 2003, 2010). On the other hand, sugar supply results in a decrease or total block in storage lipid breakdown (Eastmond et al. 2000; To et al. 2002). Our experiments were conducted on in vitro grown embryo axes and cotyledons of three lupine species (yellow, white and Andean) which are significantly different in seed storage lipid content. The regulatory function of sucrose in storage compound mobilization was investigated at ultrastructure level and by investigating the metabolism of exogenously applied ${ }^{14} \mathrm{C}$-acetate. The results of our studies enabled us to determine how two major storage compounds are catabolized in germinating lupine seeds and to gain more insight into the interconnections between pathways of storage protein and storage lipid degradation. Our studies also provided an answer to our question at what degree the limited supply of main respiratory substrates, which are amino acids in germinating lupine seeds, can be compensated by enhanced storage lipid breakdown? 


\section{Materials and methods}

Plant material and growth conditions

Seeds of yellow, white and Andean lupine were surface sterilized in $0.02 \%$ mercuric chloride for $10-15 \mathrm{~min}$ and allowed to imbibe for $24 \mathrm{~h}$ at $25^{\circ} \mathrm{C}$ in darkness. Embryo axes and cotyledons were excised from imbibed seeds and were grown in vitro for $96 \mathrm{~h}$ on Heller (1954) medium supplemented with $60 \mathrm{mM}$ sucrose $(+\mathrm{S})$ or without the sugar $(-\mathrm{S})$. The in vitro culture was kept in darkness at $25^{\circ} \mathrm{C}$.

Preparation of tissues for transmission electron microscopy (TEM)

Ultrastructure observations were made in meristematic zone of embryo axes and in parenchyma cells of the central part of cotyledons. Embryo axes and cotyledons of dry seeds, imbibed seeds ( $24 \mathrm{~h})$, and seed organs grown in vitro for $96 \mathrm{~h}$ on medium with $60 \mathrm{mM}$ saccharose $(+S)$ or on medium without the sugar $(-S)$ were used. Appropriate fragments of embryo axes and cotyledons were fixed in Carnoy's half-strength fixative (Karnowsky 1965), i.e. in a mixture of $4 \%$ glutaraldehyde and $4 \%$ paraformaldehyde $(1 / 1 \mathrm{v} / \mathrm{v})$. Postfixation was conducted in $1 \% \mathrm{OsO}_{4}$. The samples were stained in $2 \%$ aqueous solution of uranyl acetate. Dehydration was performed in a series of acetone solutions. The samples were embedded in epoxy resin of low viscosity (Spurr 1969). Ultrathin sections were prepared using Ultracut S Raichert, stained in 5\% uranyl acetate and $0.5 \%$ lead citrate and observed under the transmission electron microscope TEM-1200 Ex JEOL.
Respiration of embryo axes and cotyledons

Assay of respiration of yellow lupine embryo axes and cotyledons was performed with a Clark electrode (Rank Bothers, Digital Model 10). The organs were incubated in Petri dishes in $8 \mathrm{ml}$ of Heller medium $(+\mathrm{S}$ and $-\mathrm{S})$ supplemented with $\mathrm{NaF}$ (inhibitor of glycolysis/gluconeogenesis) and mixture of $\mathrm{KCN}, \mathrm{NaN}_{3}$ and SHAM (inhibitors of mitochondrial respiration). After $105 \mathrm{~min}$ of incubation, the embryo axes and cotyledons were transferred into a vessel of Clark electrode containing $3 \mathrm{ml}$ of incubation media and the respiration was measured during the next $15 \mathrm{~min}$. The following concentrations of the inhibitors were used: $30 \mathrm{mM} \mathrm{NaF}, 0.035 \mathrm{mM} \mathrm{KCN}, 0.035 \mathrm{mM} \mathrm{NaN}_{3}$ and $0.15 \mathrm{mM}$ SHAM.

\section{Experiments with radiolabeled acetate}

Radiolabeled experiments were conducted according to modified method described previously (Borek et al. 2003). Embryo axes (8 samples) and cotyledons (8 samples of yellow and Andean lupine and 6 samples of white lupine) grown in vitro were incubated in $8 \mathrm{ml}$ of Heller medium $(+\mathrm{S}$ and $-\mathrm{S}$ ) containing $30 \mathrm{mM} \mathrm{NaF}$ (inhibitor of glycolysis/gluconeogenesis), mixture of $0.035 \mathrm{mM} \mathrm{KCN}$, $0.035 \mathrm{mM} \mathrm{NaN}_{3}, 0.15 \mathrm{mM}$ SHAM (inhibitors of mitochondrial respiration) or $1 \mathrm{mM}$ MSO (inhibitor of glutamine synthetase). Concentrations of $\mathrm{NaF}, \mathrm{KCN}, \mathrm{NaN}_{3}$ and SHAM were adjusted so that after 120 min of incubation of the organs, their respiration rate decreased by about $50 \%$ (Table 1). MSO concentration was determined upon literature data (Masclaux-Daubresse et al. 2006). Embryo axes

Table 1 Respiration of yellow lupine embryo axes and cotyledons grown in vitro for $96 \mathrm{~h}$ on medium containing $60 \mathrm{mM}$ sucrose $(+\mathrm{S})$ or on medium without sucrose $(-\mathrm{S})$

\begin{tabular}{|c|c|c|c|c|}
\hline \multirow[t]{2}{*}{ Experimental variant } & \multicolumn{2}{|l|}{ Embryo axes } & \multicolumn{2}{|l|}{ Cotyledons } \\
\hline & $\mathrm{nmol} \mathrm{O}_{2} \min ^{-1} \mathrm{~g}^{-1} \mathrm{FW}$ & $\%$ of control & $\mathrm{nmol} \mathrm{O}_{2} \min ^{-1} \mathrm{~g}^{-1} \mathrm{FW}$ & $\%$ of control \\
\hline \multicolumn{5}{|l|}{$+\mathrm{S}$} \\
\hline Control & $77.6 \pm 2.0$ & 100 & $132.7 \pm 10.0$ & 100 \\
\hline $30 \mathrm{mM} \mathrm{NaF}$ & $38.0 \pm 2.9$ & 49 & $71.7 \pm 5.9$ & 54 \\
\hline $\begin{array}{l}\text { Mixture of: } \\
0.035 \mathrm{mM} \mathrm{KCN} \\
0.035 \mathrm{mM} \mathrm{NaN}_{3} \\
0.150 \mathrm{mM} \mathrm{SHAM}\end{array}$ & $35.7 \pm 2.1$ & 46 & $66.4 \pm 6.1$ & 50 \\
\hline \multicolumn{5}{|l|}{$-\mathrm{S}$} \\
\hline Control & $56.7 \pm 2.9$ & 100 & $138.7 \pm 10.1$ & 100 \\
\hline $30 \mathrm{mM} \mathrm{NaF}$ & $30.6 \pm 2.8$ & 54 & $73.5 \pm 7.4$ & 53 \\
\hline $\begin{array}{l}\text { Mixture of } \\
0.035 \mathrm{mM} \mathrm{KCN} \\
0.035 \mathrm{mM} \mathrm{NaN}_{3} \\
0.150 \mathrm{mM} \mathrm{SHAM}^{-15}\end{array}$ & $26.6 \pm 1.5$ & 47 & $68.0 \pm 5.2$ & 49 \\
\hline
\end{tabular}


and cotyledons were incubated in inhibitor solutions for $60 \mathrm{~min}$ and after this accommodation period, $925 \mathrm{kBq}$ of 1- or $2-{ }^{14} \mathrm{C}$ acetate was added into incubation media. Pieces of filter paper soaked with $200 \mu \mathrm{l}$ of $20 \% \mathrm{KOH}$ were placed above the surface of the incubation media. The pieces were removed in 15-min intervals, i.e. at 75, 90, 105 and $120 \mathrm{~min}$ of incubation period, and their radioactivity was measured using Packard Tri-Carb 2100 scintillation counter. Control incubations were performed since acetate is a volatile compound. $1-$ and $2-{ }^{14} \mathrm{C}$ acetate $(925 \mathrm{kBq})$ was added to $8 \mathrm{ml}$ of distilled water to assess the level of spontaneous release of ${ }^{14} \mathrm{CO}_{2}$. The radioactivity of ${ }^{14} \mathrm{CO}_{2}$ released under control conditions was subtracted from the values measured in experimental variants with embryo axes and cotyledons. After 120 min of incubation, embryo axes and cotyledons were collected, washed in distilled water and transferred to $8 \mathrm{ml}$ of $80 \%$ ethanol. After 2 weeks, the plant material was air-dried for $24 \mathrm{~h}$. The radioactivity of ethanol-soluble and -insoluble fractions of organs was measured using Packard Tri-Carb 2100 scintillation counter.

\section{Statistical analysis}

Data presented in Figs. 5, 6, 7 and in Tables 1, 2, 3, 4 are means of three replications. SD was calculated and did not exceed 10\%. In Figs. 2, 3, 4and in Tables 2, 3, 4, the SD values were omitted to clarify the presentation.

\section{Results}

Ultrastructure of embryo axes and cotyledons

In embryo axes and cotyledons of mature, air-dried seeds of yellow, white and Andean lupine, protein and oil were two major storage compounds detected, while no starch grains were visible (Figs. 2, 3, 4a, e). Storage protein was located nearly exclusively in cotyledons (Figs. 2, 3, 4e), whereas oil bodies occurred mostly in cotyledons, and occasionally in embryo axes (Figs. 2, 3, 4a, e). In embryo axes and cotyledons, oil bodies were located as a single or double layer near the plasmalemma (Figs. 2, 3, 4a, b). In cotyledons, oil bodies occurred near the plasmalemma and additionally were scattered throughout cytosol (Figs. 2, 3, 4e, f). Ultrastructure observations clearly showed differences in oil body number in seeds of the three investigated lupine species. The differences were visible both in embryo axes and in cotyledons of dry and imbibed seeds. The least oil bodies were visible in embryo axes and cotyledons of yellow lupine seeds (Fig. 2a, b, e, f). Clearly more oil bodies could be detected in organs of white lupine seeds (Fig. 3a, b, e, f), while the most oil bodies were observed in embryo axes and

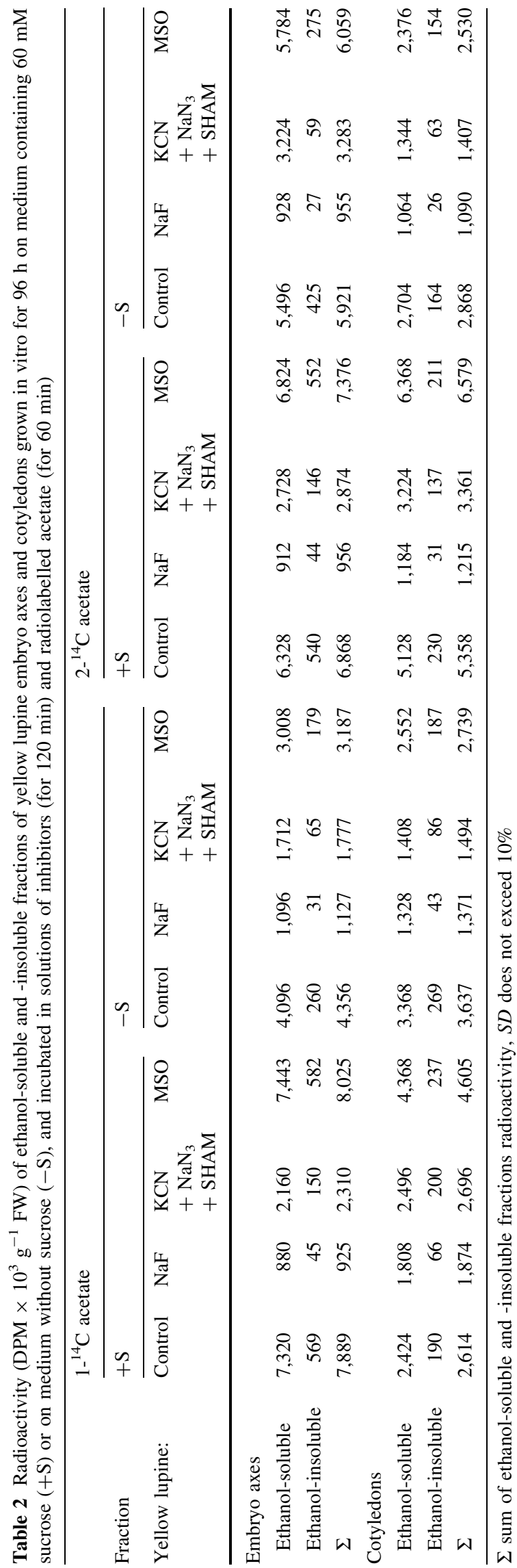




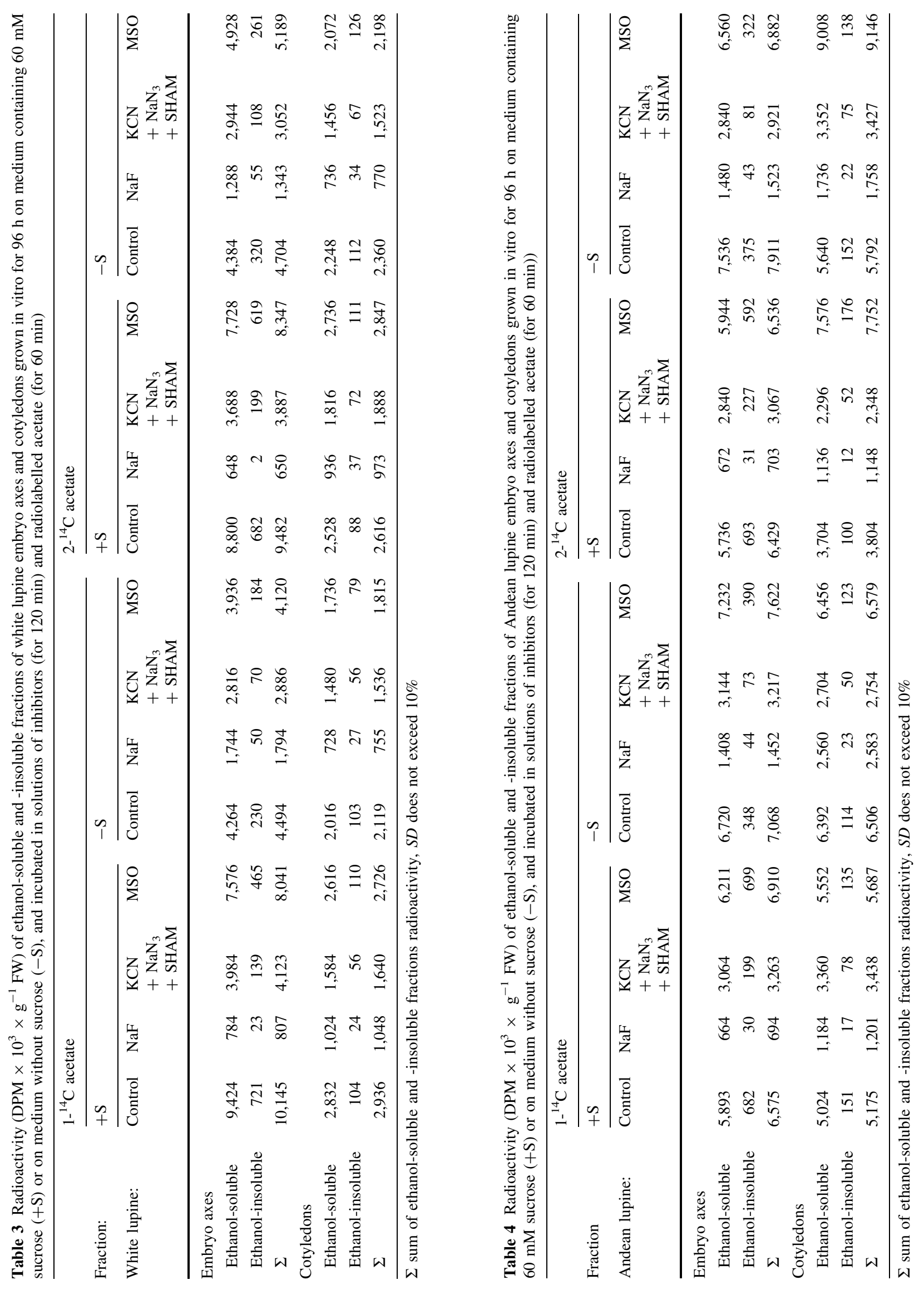



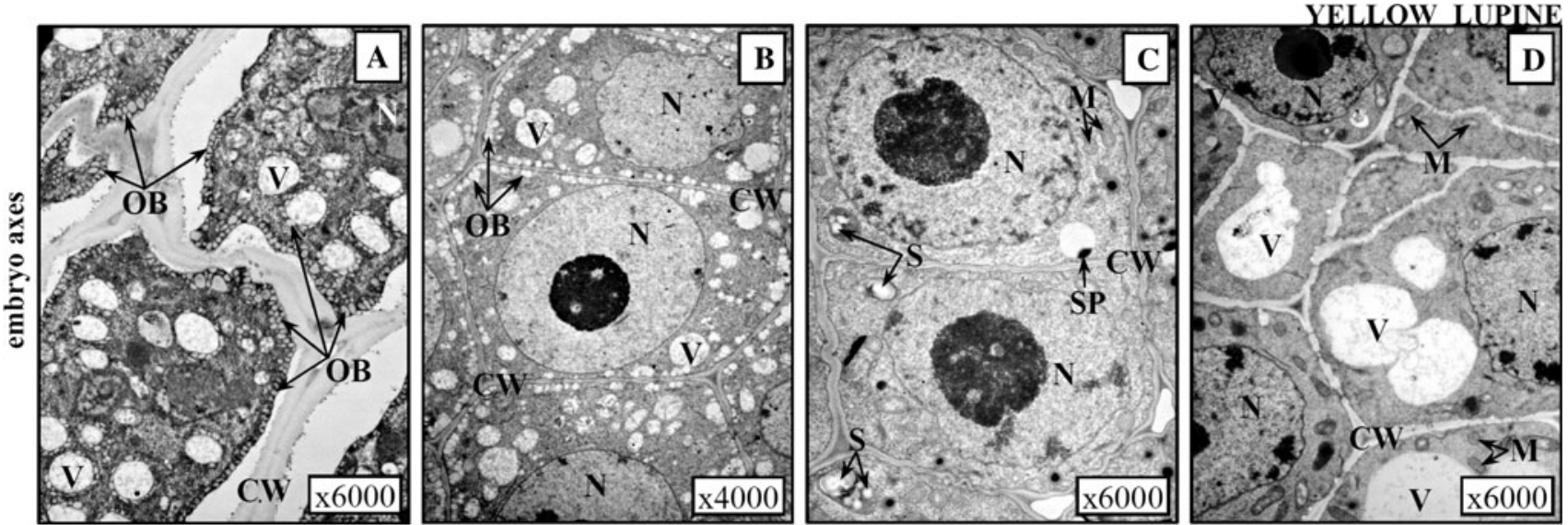

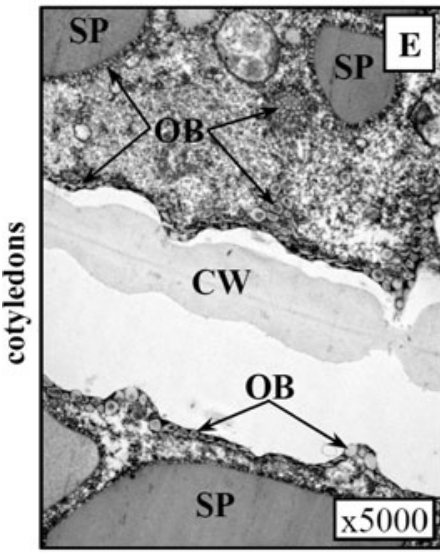

dry seeds

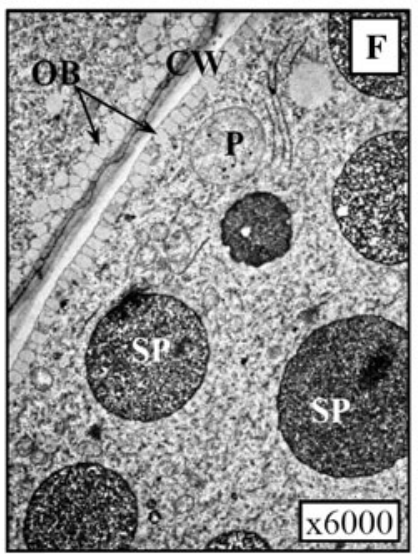

imbibed seeds

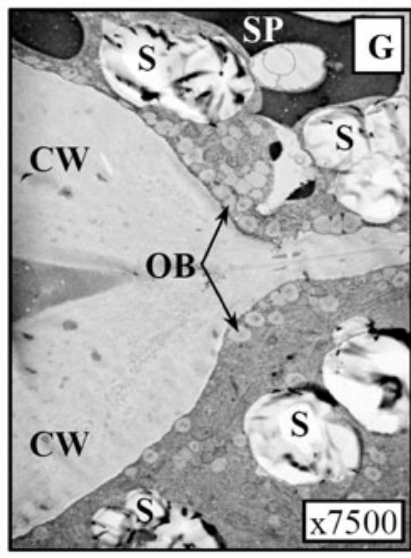

$+\mathrm{S}$

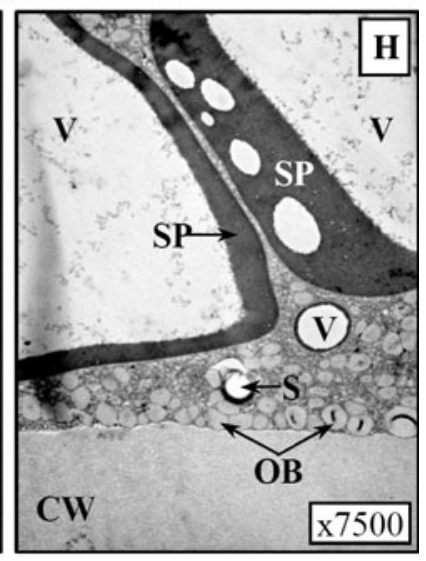

$-\mathrm{S}$
Fig. 2 Electron micrographs of yellow lupine embryo axes (root meristematic zone a-d) and cotyledons (parenchyma cells $\mathbf{e}-\mathbf{h}$ ). Embryo axes and cotyledons of dry seeds (a, e, respectively), imbibed seeds (b and $\mathbf{f}$, respectively), and grown in vitro for $96 \mathrm{~h}$ on medium

cotyledons of Andean lupine seeds (Fig. 4a, b, e, f). Starch appeared in embryo axes and cotyledons during imbibition of white lupine seeds. Numerous small or quite large starch grains were located in embryo axes (Fig. 3b), and the smaller ones occurred in cotyledons (Fig. 3f). However, starch grains did not occur in organs of imbibed seeds of yellow (Fig. 2b, f) and Andean lupine (Fig. 4b, f).

Apparent differences were noted in ultrastructure of embryo axes and cotyledons grown for $96 \mathrm{~h}$ in vitro on medium with $(+S)$ and without $(-S)$ sucrose. In yellow lupine embryo axes grown on medium $+\mathrm{S}$ oil bodies were completely degraded, small starch grains and very small amount of storage protein were visible (Fig. 2c). In sucrose starved $(-S)$ yellow lupine embryo axes there were no oil bodies, while starch and protein level and additionally the vacuolization of cells was significantly increased (Fig. 2d). In white lupine embryo axes fed with sucrose $(+S)$, few oil bodies and numerous large starch grains were visible (Fig. 3c). High vacuolization indicating advanced autophagy occurred in cells of sucrose starved $(-\mathrm{S})$ embryo axes. with $60 \mathrm{mM}$ sucrose $(+\mathrm{S} ; \mathbf{c}, \mathbf{g}$, respectively) or on medium without the sugar ( $-\mathrm{S} ; \mathbf{d}, \mathbf{h}$, respectively). $C W$ cell wall, $M$ mitochondrion, $N$ nucleus, $O B$ oil body, $P$ plastid, $S$ starch, $S P$ storage protein, $V$ vacuole
Moreover, more oil bodies were visible, compared to organs fed with sucrose (Fig. 3d). In Andean lupine embryo axes grown on medium supplemented with sucrose $(+\mathrm{S})$, there where clearly more oil bodies than in analogous embryo axes of white lupine. Small and not numerous starch grains and small deposits of storage protein were visible (Fig. 4c). In Andean lupine embryo axes grown on sucrose-free medium ( $-\mathrm{S})$, increased content of oil bodies and increased vacuolization was detected (Fig. 4d). In cotyledons grown in vitro, changes caused by culture trophy conditions were similar in all three lupine species: in cotyledons grown on medium without sucrose $(-S)$, smaller and fewer starch grains, smaller amount of storage protein, and fewer oil bodies than in sucrose fed cotyledons, were observed $(+\mathrm{S}$; Figs. 2, 3, 4g, h).

\section{Respiration of embryo axes and cotyledons}

The respiration of yellow lupine cotyledons was higher than that of embryo axes. The trophic conditions of in vitro 

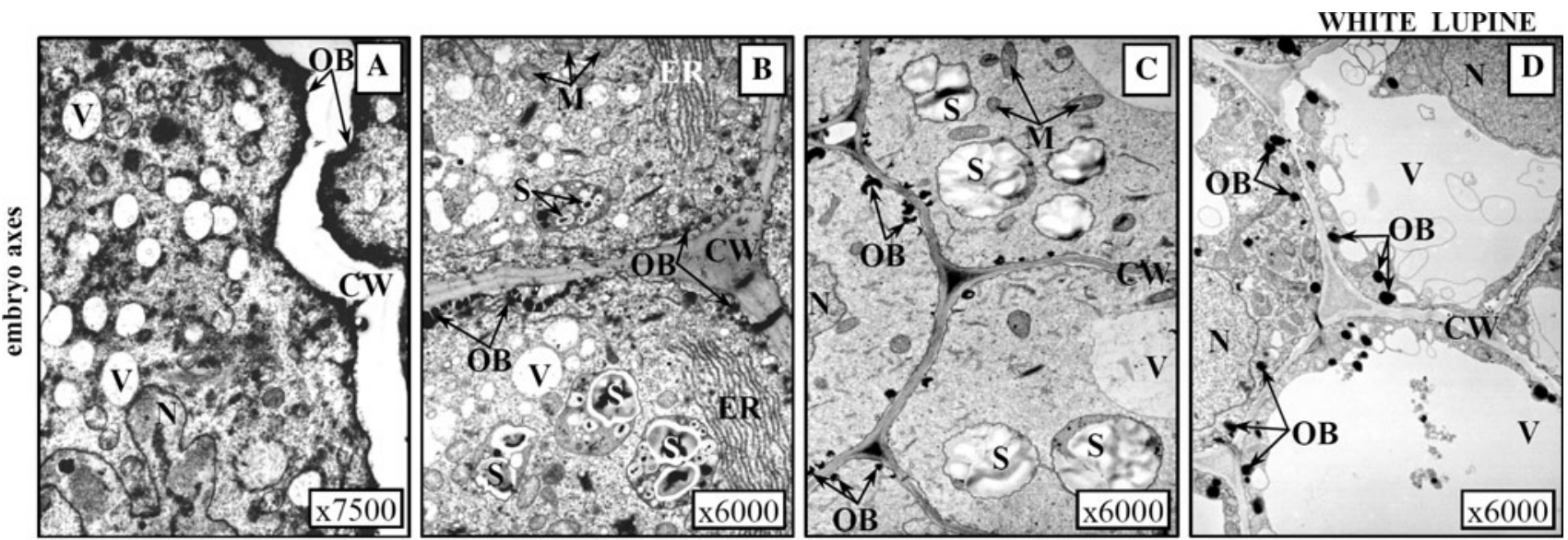

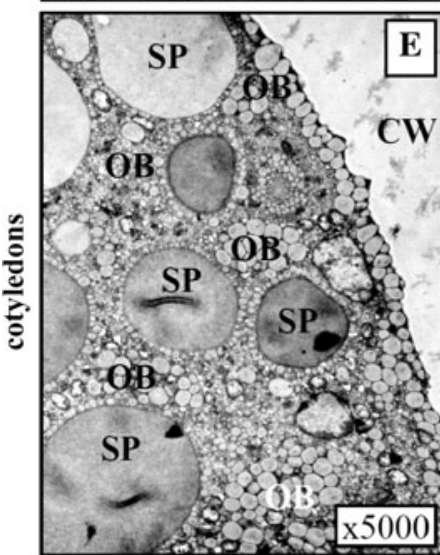

dry seeds

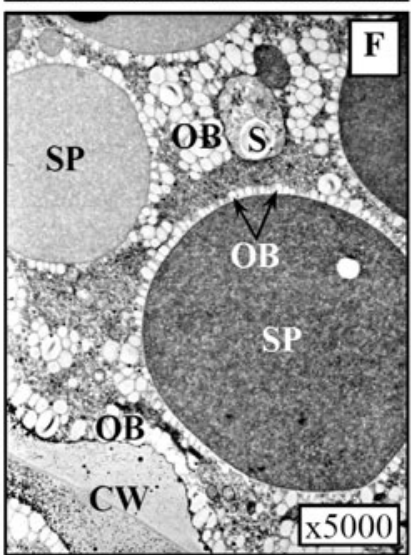

imbibed seeds

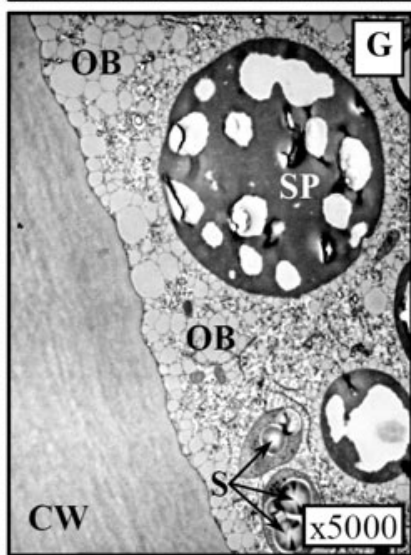

$+\mathbf{S}$

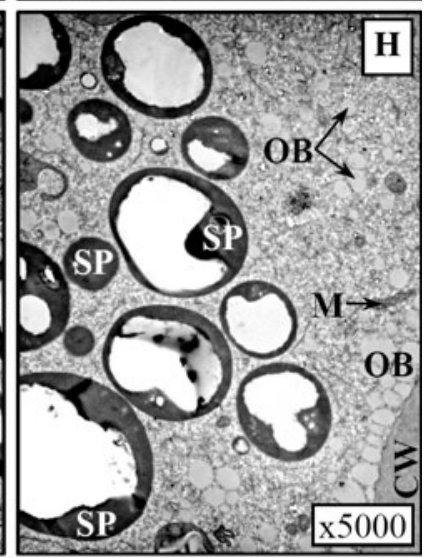

$-\mathrm{S}$
Fig. 3 Electron micrographs of white lupine embryo axes (root meristematic zone a-d) and cotyledons (parenchyma cells $\mathbf{e}-\mathbf{h}$ ). Embryo axes and cotyledons of dry seeds (a, e, respectively), imbibed seeds (b, f, respectively), and grown in vitro for $96 \mathrm{~h}$ on medium with
$60 \mathrm{mM}$ sucrose $(+\mathrm{S}$; $\mathbf{c}, \mathbf{g}$, respectively) or on medium without the sugar $(-\mathrm{S} ; \mathbf{d}, \mathbf{h}$, respectively). $C W$ cell wall, $E R$ endoplasmic reticulum, $M$ mitochondrion, $N$ nucleus, $O B$ oil body, $S$ starch, $S P$ storage protein, $V$ vacuole culture $(+\mathrm{S}$ and $-\mathrm{S})$ did not cause significant change in $\mathrm{O}_{2}$ consumption by cotyledons but respiration of sucrose starved ( $-\mathrm{S})$ embryo axes was considerably lower than respiration of embryo axes fed with sucrose $(+S)$ (control in Table 1).

Radioactivity of $\mathrm{CO}_{2}$ produced from acetate by embryo axes and cotyledons

Small amounts of radioactive $\mathrm{CO}_{2}$ released by embryo axes and cotyledons from $1-$ and $2-{ }^{14} \mathrm{C}$ acetate were detected after $15 \mathrm{~min}$ of incubation. From this stage, the level of $\mathrm{CO}_{2}$ radioactivity has been increasing exponentially to the end of experimental period, i.e. till 120 min (Figs. 5, 6, 7ah). Remarkably higher release of radioactive $\mathrm{CO}_{2}$ was noted from $1-{ }^{14} \mathrm{C}$ (Figs. 5, 6, 7a, c, e, g) than from $2-{ }^{14} \mathrm{C}$ (Figs. 5, 6, 7b, d, f, h) acetate. It was most clearly visible in yellow and Andean lupine cotyledons where radioactivity of $\mathrm{CO}_{2}$ with carbon atom from $\mathrm{C}-1$ position of acetate was almost 20-fold higher than radioactivity of $\mathrm{CO}_{2}$ with carbon atom from C-2 position of acetate (control on Fig. 5g, h and MSO on Fig. 7e, f, respectively). In all three lupine species, more radioactive $\mathrm{CO}_{2}$ (both from 1- and $2-{ }^{14} \mathrm{C}$ acetate) was released by embryo axes (Figs. 5, 6, 7a-d) than cotyledons (Figs. 5, 6, 7e-h) and this liberation was clearly higher (without few exceptions) in organs grown on medium without sucrose $(-\mathrm{S})$. It was the most evident in starved embryo $(-\mathrm{S})$ axes of yellow and white lupine which produced ${ }^{14} \mathrm{CO}_{2}$ from $2-{ }^{14} \mathrm{C}$ acetate over sixfold more intensely than embryo axes fed with sucrose $(+\mathrm{S})$ (controls on Figs. 5b, d, 6b, d, respectively). Among the inhibitors, $\mathrm{NaF}$ caused the highest suppression in liberation of ${ }^{14} \mathrm{CO}_{2}$ (both from 1- and $2-{ }^{14} \mathrm{C}$ acetate) in all studied organs (Figs. 5, 6, 7a-h). The mixture of $\mathrm{KCN}, \mathrm{NaN}_{3}$ and SHAM caused inhibition of ${ }^{14} \mathrm{CO}_{2}$ production as well, but to a lesser extend than $\mathrm{NaF}$ (Figs. 5, 6, 7a-h); in two cases a stimulatory effect on ${ }^{14} \mathrm{CO}_{2}$ liberation was observed (liberation of $\mathrm{CO}_{2}$ with $\mathrm{C}-2$ of acetate by white lupine embryo axes and cotyledons grown on $+\mathrm{S}$ medium; Fig. 6b, f). MSO stimulated liberation of ${ }^{14} \mathrm{CO}_{2}$ in embryo 


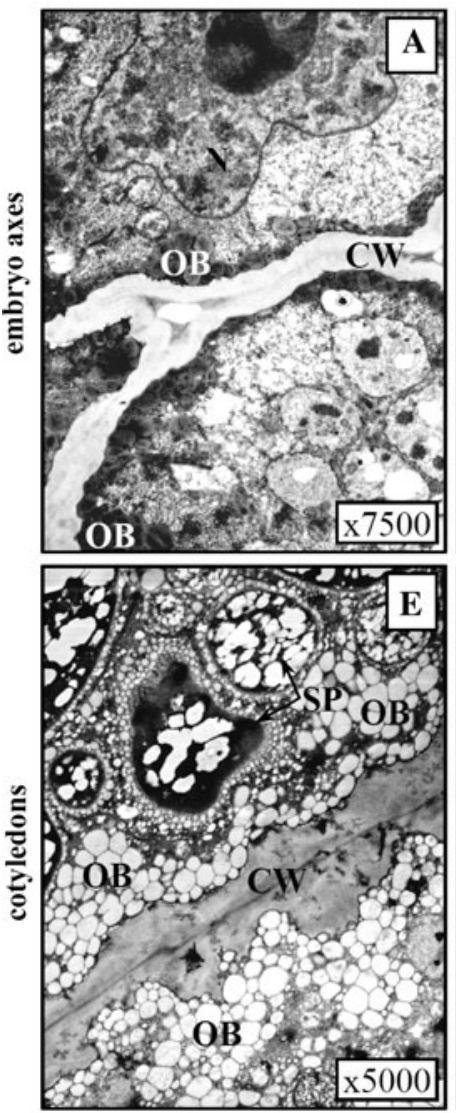

dry seeds
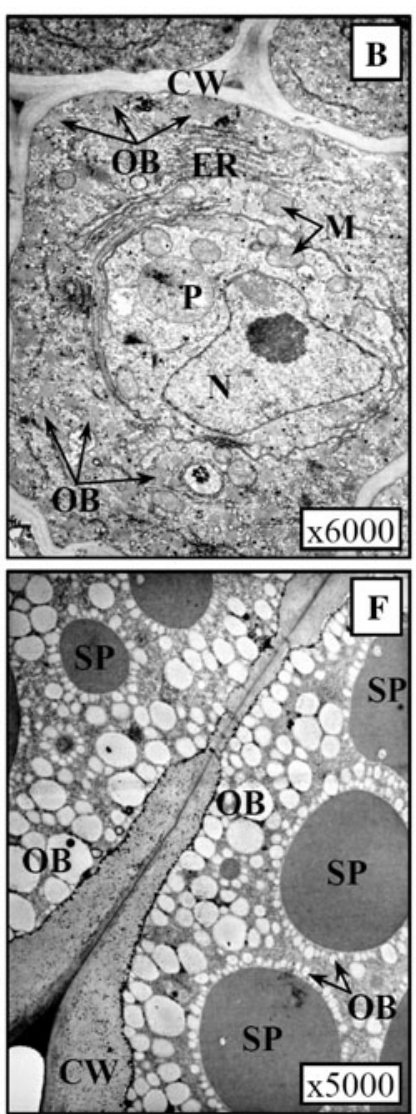

imbibed seeds
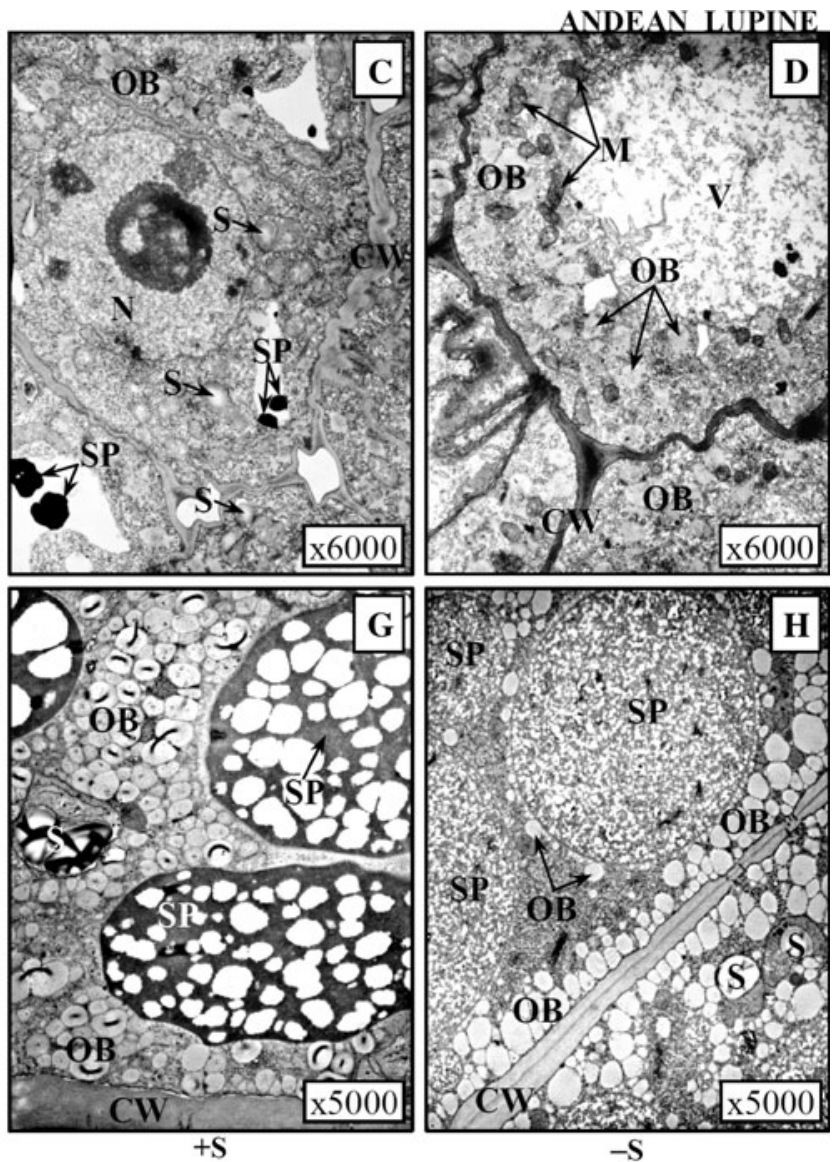

Fig. 4 Electron micrographs of Andean lupine embryo axes (root meristematic zone $\mathbf{a}-\mathbf{d}$ ) and cotyledons (parenchyma cells $\mathbf{e}-\mathbf{h}$ ). Embryo axes and cotyledons of dry seeds (a, e, respectively), imbibed seeds (b, f, respectively), and grown in vitro for $96 \mathrm{~h}$ on medium with

axes and cotyledons of yellow lupine and white lupine grown on medium with sucrose $(+S)$ (Figs. 5a, b, e, f, 6a, $\mathrm{b}, \mathrm{e}, \mathrm{f}$, respectively). In Andean lupine, MSO caused higher production ${ }^{14} \mathrm{CO}_{2}$ compared to the control both in organs grown on medium with $(+S)$ and without sucrose $(-S)$ (Fig. 7a-h).

Radioactivity of ethanol fractions of embryo axes and cotyledons

Generalizations are necessary when describing the radioactivity of ethanol-soluble and -insoluble fractions. In all three investigated species, considerably more radioactivity was found in ethanol fractions than in the liberated ${ }^{14} \mathrm{CO}_{2}$ (Tables 2, 3, 4). Ethanol-soluble fraction was more radioactive than the -insoluble one. Embryo axes accumulated radioactivity with higher efficiency than cotyledons (Table 2, 3, 4). The difference was the highest in sucrosefed $(+S)$ embryo axes of white lupine that accumulated over threefold more radioactivity than cotyledons (the sum of ethanol-soluble and -insoluble fractions of $+\mathrm{S}$ controls

$60 \mathrm{mM}$ sucrose $(+\mathrm{S}$; c, g, respectively) or on medium without the sugar $(-\mathrm{S} ; \mathbf{d}, \mathbf{h}$, respectively). $C W$ cell wall, $E R$ endoplasmic reticulum, $M$ mitochondrion, $N$ nucleus, $O B$ oil body, $S$ starch, $S P$ storage protein, $V$ vacuole

in Table 3). The lack of sucrose in medium $(-S)$ caused a decrease in the radioactivity of ethanol-soluble and -insoluble fractions of yellow (with one exception) and white lupine embryo axes and cotyledons (compare $+\mathrm{S}$ and $-S$ controls in Tables 2, 3), whereas in Andean lupine it caused an increase in the fractions' radioactivity (Table 4). The accumulation of carbon atoms from C-1 and C-2 positions of acetate in embryo axes and cotyledons was at a similar level. The respiratory inhibitors, with few exceptions, caused the same effect on the radioactivity of ethanol-soluble and -insoluble fractions, like on ${ }^{14} \mathrm{CO}_{2}$ liberation, i.e. the radioactivity of ethanol fractions was strongly decreased by $\mathrm{NaF}$ and to a lesser degree by the mixture of $\mathrm{KCN}, \mathrm{NaN}_{3}$ and SHAM (Tables 2, 3, 4). The changes in radioactivity of ethanol fractions caused by MSO were similar to those observed in ${ }^{14} \mathrm{CO}_{2}$ liberation by embryo axes and cotyledons of only yellow and Andean lupine. In yellow lupine, MSO caused an increase in radioactivity in organs fed with sucrose $(+S)$ and decrease in organs grown on $-S$ medium (Table 2). In Andean lupine, MSO caused an increase of ethanol fractions 

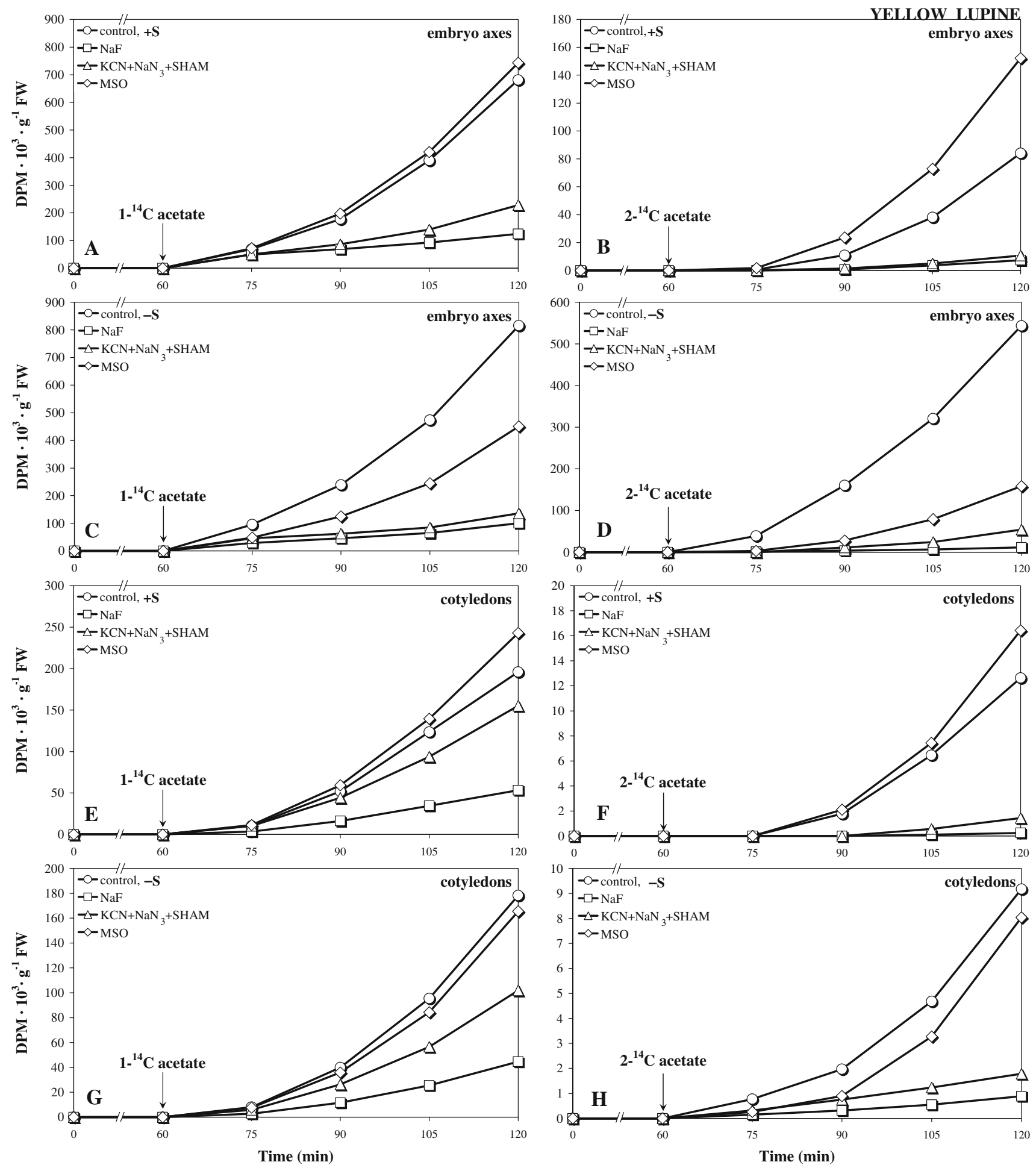

Fig. 5 Radioactivity of $\mathrm{CO}_{2}$ with ${ }^{14} \mathrm{C}$ from $1-{ }^{14} \mathrm{C}$ - (ACEG) and $2-{ }^{14} \mathrm{C}$-acetate $(\mathrm{BDFH})$ released by yellow lupine embryo axes (ad) and cotyledons (e-h) grown in vitro for $96 \mathrm{~h}$ on medium containing $60 \mathrm{mM}$ sucrose $(+\mathrm{S})(\mathbf{a}, \mathbf{b}, \mathbf{e}, \mathbf{f})$ or on medium without

radioactivity of both organs grown on $+\mathrm{S}$ and $-\mathrm{S}$ media (Table 4). Larger and ambiguous divergences were observed in MSO influence on radioactivity accumulation sucrose $(-\mathrm{S})(\mathbf{c}, \mathbf{d}, \mathbf{g}, \mathbf{h})$, and incubated in solutions of inhibitors (for $120 \mathrm{~min}$ ) and radiolabelled acetate (for $60 \mathrm{~min}$ ). SD does not exceed $10 \%$

in white lupine embryo axes and cotyledons. In this species MSO decreased radioactivity coming from $1-{ }^{14} \mathrm{C}$ acetate in fractions of organs grown on $+\mathrm{S}$ and $-\mathrm{S}$ media (Table 3). 

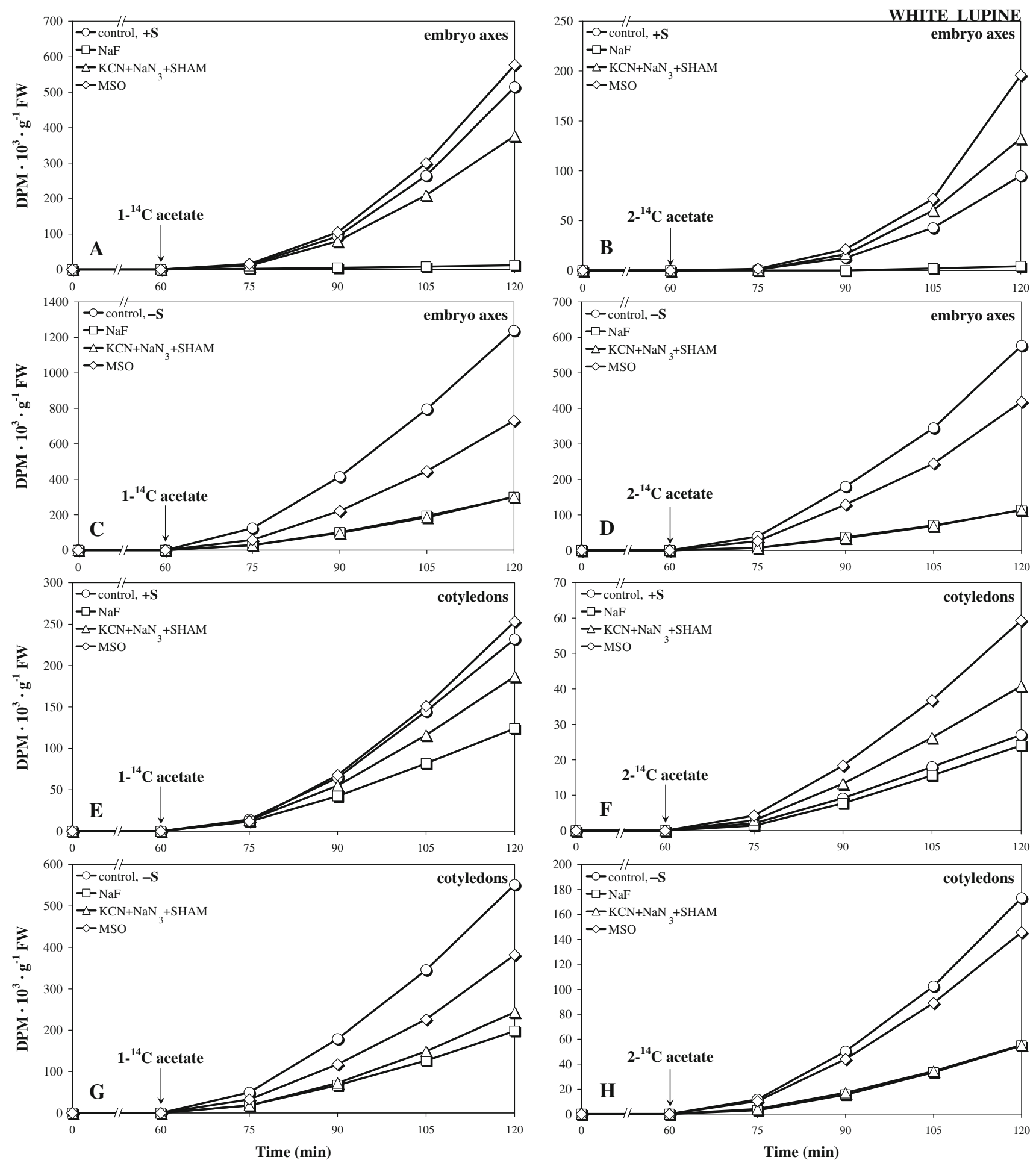

Fig. 6 Radioactivity of $\mathrm{CO}_{2}$ with ${ }^{14} \mathrm{C}$ from $1-{ }^{14} \mathrm{C}-(\mathbf{a}, \mathbf{c}, \mathbf{e}, \mathbf{g})$ and ${ }_{2-}{ }^{14} \mathrm{C}$-acetate $(\mathbf{b}, \mathbf{d}, \mathbf{f}, \mathbf{h})$ released by white lupine embryo axes (ad) and cotyledons (e-h) grown in vitro for $96 \mathrm{~h}$ on medium containing $60 \mathrm{mM}$ sucrose $(+\mathrm{S})(\mathbf{a}, \mathbf{b}, \mathbf{e}, \mathbf{f})$ or on medium without

\section{Discussion}

The results presented in this paper show that sugar level in tissues controls the intensity of storage compound

sucrose $(-S)(\mathbf{c}, \mathbf{d}, \mathbf{g}, \mathbf{h})$, and incubated in solutions of inhibitors (for $120 \mathrm{~min}$ ) and radiolabelled acetate (for $60 \mathrm{~min}$ ). SD does not exceed $10 \%$

breakdown during germination of protein-storing lupine seeds. In lupine embryo axes and cotyledons grown in vitro on medium without sucrose $(-\mathrm{S})$, a decreased concentration of soluble sugars and lower content of temporary 

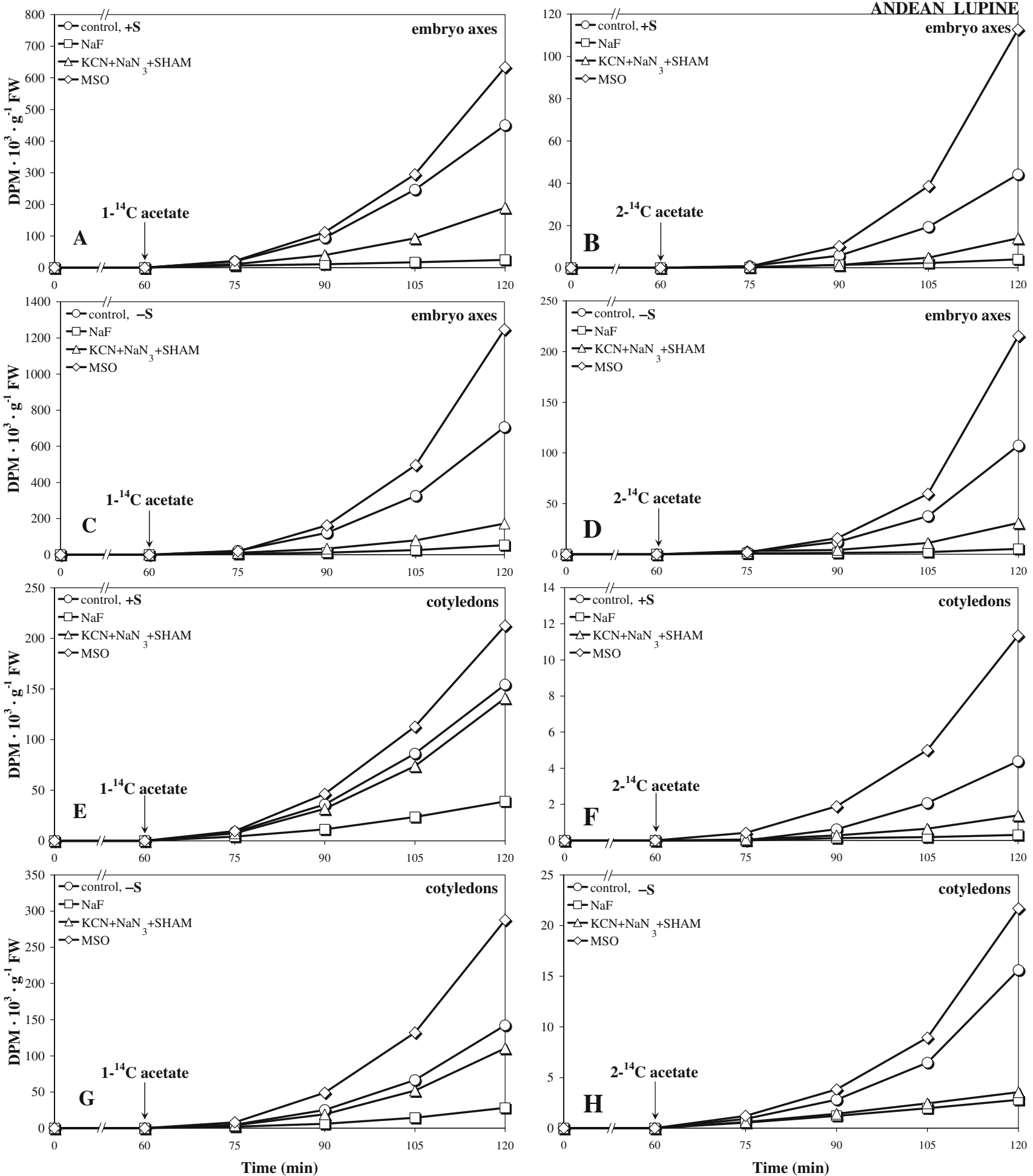

Fig. 7 Radioactivity of $\mathrm{CO}_{2}$ with ${ }^{14} \mathrm{C}$ from $1-{ }^{14} \mathrm{C}-(\mathbf{a}, \mathbf{c}, \mathbf{e}, \mathbf{g})$ and $2-{ }^{14} \mathrm{C}$-acetate $(\mathbf{b}, \mathbf{d}, \mathbf{f}, \mathbf{h})$ released by Andean lupine embryo axes $(\mathbf{a}-$ d) and cotyledons (e-h) grown in vitro for $96 \mathrm{~h}$ on medium containing $60 \mathrm{mM}$ sucrose $(+\mathrm{S})(\mathbf{a}, \mathbf{b}, \mathbf{e}, \mathbf{f})$ or on medium without

starch is observed (Borek et al. 2006). Decreasing of sugar concentration in tissues causes changes in the metabolism that allow supplying of respiratory substrates. A proof for

sucrose $(-\mathrm{S})(\mathbf{c}, \mathbf{d}, \mathbf{g}, \mathbf{h})$, and incubated in solutions of inhibitors (for $120 \mathrm{~min}$ ) and radiolabelled acetate (for $60 \mathrm{~min}$ ). SD does not exceed $10 \%$

enhancement of storage compound degradation in sugar depletion conditions are changes observed in ultrastructure of embryo axes and cotyledons of all three investigated 
lupine species. Changes visible in ultrastructure of cotyledons were unambiguous and dependent on decreasing of storage protein content, oil content, and frequency and size of starch grains (Figs. $2 \mathrm{~g}, \mathrm{~h}-4 \mathrm{~g}, \mathrm{~h}$ ). In cells of root meristematic zone of sucrose starved $(-S)$ embryo axes, an increased vacuolization level was observed despite of diminishing or disappearing of storage protein and starch (Figs. 2c, d, 3, 4c, d). This indicates on advanced autophagy (Marty 1999), which is a mechanism for degradation of cellular contents in order to recycle nutrients, especially protein (Thompson and Vierstra 2005). In plants, autophagy has been known to be important for nutrient remobilization during sugar and/or nitrogen starvation (Thompson and Vierstra 2005; Lundgren Rose et al. 2006; Bassham 2007). In sucrose starved $(-S)$ white and Andean lupine embryo axes, numerous oil bodies were noticed (Figs. 3c,d, $4 \mathrm{c}, \mathrm{d})$. This observation is surprising and difficult to interpret. However, as autophagy causes massive and nonspecific degradation of plasma membranes (Aubert et al. 1996), we hypothesize that the second source (besides lipid stored in oil bodies) of fatty acids appears in cells. Moreover, in such conditions, the synthesis of the new compounds of plasma membranes is restricted. Contrary to this, in conditions of good supply of tissues in sugars $(+S)$, more intensive growth of white and Andean lupine embryo axes occurs (data not presented), so oil bodies are degraded faster. Because of that, in sucrose fed $(+\mathrm{S})$ white and Andean lupine embryo axes there are less numerous oil bodies than in sucrose starved $(-S)$ ones. Additionally, since one of the main aims of autophagy during starvation is the supply of respiratory substrates (which in germinating lupine seeds are amino acids), this process should be induced by amino acids deficit. It is possible that vacuolization, as a result of autophagy, could be visible in cells even before total degradation of oil bodies. This was observed in white and Andean lupine embryo axes, because seeds of those species contain relatively a lot of storage lipid (7-14 and about 20\%, respectively) (Borek et al. 2009). Yellow lupine seeds contain less storage lipid (about 6\%) (Borek et al. 2009), so it was completely mobilized before the non-specific, autophagic degradation occurred. The higher content of oil bodies in sucrose starved $(-\mathrm{S})$ embryo axes corresponds with the analytical measurements of the total lipid content in whole lupine organs grown in vitro. They show the higher total lipid content in starved $(-S)$ than in sucrose fed $(+S)$ embryo axes (data not presented). Autophagic processes were not visible in cells of cotyledons, because the lack of sucrose in the culture medium did not generate sugar starvation in these organs during $96 \mathrm{~h}$.

Exogenously applied acetate was taken up by embryo axes and cotyledons and accumulated in large quantities in organ fractions (controls in Tables 2, 3, 4). However, some of it was released as ${ }^{14} \mathrm{CO}_{2}$ (Figs. 5, 6, 7), which suggests that acetate was used as a respiratory substrate as well (after its earlier activation to acetyl-CoA) (Fig. 1). The radioactivity accumulated in organ fractions was considerably higher than that of $\mathrm{CO}_{2}$ (compare controls in Tables 2, 3, 4 and controls on Figs. 5, 6, 7). Release of ${ }^{14} \mathrm{CO}_{2}$ from exogenous acetate by organs treated with respiratory inhibitors did not correlate with $\mathrm{O}_{2}$ uptake. Respiratory inhibitors decreased respiration to about 50\% (Table 1), but $\mathrm{NaF}$ and the inhibitors of mitochondrial electron transport chain $\left(\mathrm{KCN}, \mathrm{NaN}_{3}\right.$ and SHAM) retarded oxidation of acetate considerably stronger than $\mathrm{O}_{2}$ consumption. The effect of $\mathrm{NaF}$ was stronger than that of the inhibitors of mitochondrial electron transport chain (Figs. 5, 6, 7). Such intensive inhibitory effect of $\mathrm{NaF}$ on ${ }^{14} \mathrm{CO}_{2}$ liberation (as well as on radioactivity of ethanolsoluble and -insoluble fractions; Tables 2, 3,4) is probably a result of non-specific action of $\mathrm{NaF}$. Enolase is inhibited by direct binding of fluoride to the enzyme (Qin et al. 2006). However, fluoride is considered as an agent that binds $\mathrm{Ca}^{+2}$ and $\mathrm{Mg}^{+2}$, and in that way decreases availability of these ions to many enzymes. In this way $\mathrm{NaF}$ may cause disruption in many processes. This second mechanism of inhibitory effect of $\mathrm{NaF}$ was proposed, for example, for $\mathrm{H}^{+}$-ATPase (Reddy and Kaur 2008).

The use of acetate as a respiratory substrate, was increased in organs grown on medium without sucrose $(-\mathrm{S})$. These organs produced more ${ }^{14} \mathrm{CO}_{2}$ (Figs. 5, 6, 7) and lower radioactivity of ethanol-soluble and -insoluble fractions was observed (controls in Tables 2, 3, 4). It is consistent with many literature data describing enhancement in respiring other substrates than glucose in sugar deficiency conditions (Koch 1996; Yu 1999; Devaux et al. 2003; Rolland et al. 2006; Ramon et al. 2008). Moreover, the carbon atom in radioactive $\mathrm{CO}_{2}$ originated mostly from the $\mathrm{C}-1$ position of acetate. This result indicates that TCA cycle is not the sole source of radioactive $\mathrm{CO}_{2}$. One of biochemical processes producing $\mathrm{CO}_{2}$ is the conversion of isocitrate into 2-oxoglutarate catalyzed by cytosolic $\mathrm{NADH}^{+}$-dependent isocitrate dehydrogenase (IDH) (Fig. 1). Next, 2-oxoglutarate undergoes transamination and takes part in GS/GOGAT cycle giving glutamate (Bewley and Black 1994). The activity of $\mathrm{NADH}^{+}$-IDH was proved previously in germinating yellow lupine seeds (Borek et al. 2006) and the enzyme is very important in carbon flow from fatty acids to amino acids in germinating yellow lupine seeds (Borek and Ratajczak 2010). Other source of ${ }^{14} \mathrm{CO}_{2}$ may be phosphoenolpyruvate carboxykinase (PEPCK) (Fig. 1). This enzyme takes part in gluconeogenesis and its activity in germinating yellow lupine seeds has also been detected (Ratajczak et al. 1998). However, our earlier results on yellow lupine seed germination with exogenously applied $1-$ and $2-{ }^{14} \mathrm{C}$ acetate have 
shown lower flow of radioactivity into sugars than into amino acids (Borek et al. 2003; Borek and Ratajczak 2010), which suggests restricted carbon flow through PEPCK. Therefore, the release of ${ }^{14} \mathrm{CO}_{2}$ with the carbon atoms from C-2 position may be attributed only to reactions of the TCA cycle. Higher incorporation of carbon atom from position $\mathrm{C}-1$ than $\mathrm{C}-2$ of exogenous acetate into $\mathrm{CO}_{2}$ has been previously observed in seedlings of yellow lupine and this phenomenon has been analyzed in details in our earlier publication (Borek et al. 2003).

Lupine seeds accumulate high amount of protein as a main storage compound. For example, in yellow and Andean lupine seeds protein content can reach up to $35 \%$ of dry weight (Lehmann and Ratajczak 2008). Temporary increase of free amino acids as a result of storage protein catabolism during germination is observed and glutamate occupies the central position in complex amino acid metabolism. It is a precursor of many compounds and is transaminated with many amino acids (Bewley and Black 1994). In the course of storage protein mobilization and amino acid metabolism large quantities of ammonium are produced. As nitrogen in this form is toxic (Britto and Kronzucker 2002), its utilization is necessary. Asparagine as a temporary storage form of ammonium is accumulated (up to $30 \%$ of dry weight) (Lehmann and Ratajczak 2008). Ammonium is reasimilated in two steps. First, glutamine is synthesized from glutamate and ammonium by GS and next, through the action of AS, it is stored in asparagine (Lehmann and Ratajczak 2008) (Fig. 1). A source of carbon skeletons for such intensive asparagine synthesis is necessary. Other amino acids can be one of such source, but during germination and young seedling development most of amino acids are used for protein synthesis in developing embryo axes and some of amino acids are respired (Ratajczak et al. 1996; Borek et al. 2001; Lehmann and Ratajczak 2008) (Fig. 1). Carbon skeletons for asparagine synthesis do not come from carbohydrates, because mature, air-dried yellow, white and Andean lupine seeds do not contain starch as a storage compound (Figs. 2, 3, 4a, e; Borek et al. 2006; Duranti et al. 2008). In such circumstances, fatty acids coming from storage lipid breakdown may be a source of carbon skeletons for asparagine synthesis (Fig. 1). This possibility was proved in germinating yellow lupine seeds (Borek et al. 2003; Borek and Ratajczak 2010). Several alternative pathways leading from storage lipid to asparagine are proposed. Citrate, isocitrate, malate and oxaloacetate synthesized in glyoxylate cycle are the main intermediates directed to amino acids synthesis (Fig. 1). It may be direct synthesis of amino acids from isocitrate (through 2-oxoglutarate) or oxaloacetate, or after their previous conversion into malate and 2-oxoglutarate in TCA cycle (Borek and Ratajczak 2010). The results presented here indirectly confirm carbon flow from storage lipid into amino acids in germinating lupine seeds. GS inhibitor caused an increase in $\mathrm{CO}_{2}$ radioactivity (Figs. 5, $6,7)$ and radioactivity of ethanol-soluble and -insoluble fractions of embryo axes and cotyledons (Tables 2, 3, 4). This was most evident in embryo axes and cotyledons of Andean lupine, i.e. species which seeds contain the highest (among the lupine species studied) amount of storage lipid (about $20 \%$ of dry weight) (Borek et al. 2009). Increase in $\mathrm{CO}_{2}$ and fractions radioactivity caused by MSO was observed in all experimental variants (Fig. 7a-h; Table 4). Inhibition of GS causes disruption in asparagine synthesis and simultaneous disruption in amino acids oxidation. Physiological meaning of the enhancement of lipid catabolism is obvious. A block in oxidation of main respiratory substrate, which in germinating lupine seeds are amino acids coming from storage proteins, causes an increase in catabolism of other potential respiratory substrates, i.e. fatty acids. The mechanism of this phenomenon is not known in details and needs additional research. However, our results suggest that one of the regulatory agents is the sucrose level in tissues of studied organs. Oxidation of labelled acetate was considerably higher in organs grown on $-\mathrm{S}$ medium. It was the clearest visible in $2{ }^{14} \mathrm{C}$ acetate catabolism by sucrose starved embryo axes (Figs. 5, 6, 7); however, MSO caused simultaneous increase in radioactivity of ethanol-soluble and -insoluble fractions (Tables 2, $3,4)$. So, lipid is not only a respiratory substrate, but it is also used in non-respiratory processes (Fig. 1). Using exogenous ${ }^{14} \mathrm{C}$-acetate, it has been proved previously that in germinating yellow lupine seeds lipid-derived carbon is directed more efficiently into amino acids than into sugars (Borek et al. 2003; Borek and Ratajczak 2010). Such tendency is opposite to that observed in germinated oil-storing seeds, in which storage lipid is used as respiratory substrate and is converted mainly into sugars (Beevers 1976, 1979; Eastmond and Graham 2001; Penfield et al. 2005, 2006; Graham 2008; Quettier and Eastmond 2009; Kaur et al. 2009). The data presented in this paper indicate peculiar features of lipid catabolism in germinating lupine seeds as a result of high storage protein level.

The data presented here are based on our comparative study of storage lipid breakdown and interconnections between storage lipid and protein catabolism during seed germination of three species of the lupine genus. They clearly indicate that different strategies of storage compound mobilization occur during germination depending on proportions of lipid and protein content in lupine seeds. In germinating yellow lupine seeds, which have the highest storage protein to lipid ratio (Fig. 2e-h; Lehmann and Ratajczak 2008; Borek et al. 2009), metabolism dependents on amino acids. In germinating seeds of this lupine species, amino acids are used not only for protein synthesis but are respired, too. Disruption in amino acids metabolism (MSO 
treatment) cannot be efficiently compensated by enhancement of breakdown of spare amount of storage lipid. Such situation is enhanced additionally in sugars deficiency conditions in tissues (Fig. 5c, d, g, h; Table 2). In white lupine seeds, storage protein dominates as well, but storage lipid content is higher than in yellow lupine seeds (Fig. 3e, f; Borek et al. 2009). During white lupine seeds germination, the efficient synthesis of temporary starch takes place (already during imbibition) (Fig. 2b, f). So, in germinating white lupine seeds, the very convenient storage compound appears and can be used for respiration and for anabolic processes. In such circumstances, de-organization of amino acid metabolism does not cause the quick increase in storage lipid breakdown (Fig. 6a-h; Table 3). Opposite to the two strategies of storage compounds breakdown described above, the third one is possible in germinating Andean lupine seeds. The seeds of this lupine species accumulate high amount of storage protein, but contain high amount of storage lipid as well (Fig. 4e-h; Lehmann and Ratajczak 2008; Borek et al. 2009). Because of that, in germinating Andean lupine seeds an efficient pathway of storage lipid catabolism has to occur. In the case of blocking of storage protein catabolism, the storage lipid breakdown can efficiently compensate amino acids supply and fatty acids can be used both for respiration and for anabolic processes. This strategy can function even in conditions of sucrose deficiency in tissues (Fig. 7a-h; Table 4).

Acknowledgments This work was supported by grant no. 2 P06A 00429 from Polish science funding in years 2005-2008.

Open Access This article is distributed under the terms of the Creative Commons Attribution Noncommercial License which permits any noncommercial use, distribution, and reproduction in any medium, provided the original author(s) and source are credited.

\section{References}

Aubert S, Gout E, Bligny R, Marty-Mazars D, Barrieu F, Alabouvette J, Marty F, Douce R (1996) Ultrastructural and biochemical characterization of autophagy in higher plant cells subjected to carbon deprivation: control by the supply of mitochondria with respiratory substrates. J Cell Biol 133:1251-1263

Baker A, Graham IA, Holdsworth M, Smith SM, Theodoulou FL (2006) Chewing the fat: $\beta$-oxidation in signalling and development. Trends Pl Sci 11:124-132

Bassham D (2007) Plant autophagy-more than a starvation response. Curr Opin Plant Biol 10:587-593

Beevers H (1976) Nitrogen metabolism in plants. Edward Arnold, Leonard London

Beevers H (1979) Microbodies in higher plants. Annu Rev Plant Physiol 30:159-193

Bewley JD, Black M (1994) Seeds: physiology of development and germination. Plenum Press, New York
Borek S, Ratajczak L (2010) Storage lipids as a source of carbon skeletons for asparagine synthesis in germinating seeds of yellow lupine (Lupinus luteus L.). J Plant Physiol 167:717-724

Borek S, Morkunas I, Ratajczak W, Ratajczak L (2001) Metabolism of amino acids in germinating yellow lupin seeds. III Breakdown of arginine in sugar-starved organs cultivated in vitro. Acta Physiol Plant 23:141-148

Borek S, Ratajczak W, Ratajczak L (2003) A transfer of carbon atoms from fatty acids to sugars and amino acids in yellow lupine (Lupinus luteus L.) seedlings. J Plant Physiol 160:539-545

Borek S, Ratajczak W, Ratajczak L (2006) Ultrastructural and enzymatic research on the role of sucrose in mobilization of storage lipids in germinating yellow lupine seeds. Plant Sci 170:441-452

Borek S, Pukacka S, Michalski K, Ratajczak L (2009) Lipid and protein accumulation in developing seeds of three lupine species: Lupinus luteus L., Lupinus albus L., and Lupinus mutabilis Sweet. J Exp Bot 60:3453-3466

Britto DT, Kronzucker HJ (2002) $\mathrm{NH}_{4}{ }^{+}$toxicity in higher plants: a critical review. J Plant Physiol 159:567-584

Cornah JE, Germain V, Ward JL, Beale MH, Smith SM (2004) Lipid utilization, gluconeogenesis, and seedling growth in Arabidopsis mutants lacking the glyoxylate cycle enzyme malate synthase. J Biol Chem 279:42916-42923

Courtois-Verniquet F, Douce R (1993) Lack of aconitase in glyoxysomes and peroxisomes. Biochem J 294:103-107

De Bellis L, Hayashi M, Biagi PP, Hara-Nishimura I, Alpi A, Nishimura M (1994) Immunological analysis of aconitase in pumpkin cotyledons: the absence of aconitase in glyoxysomes. Physiol Plant 90:757-762

Devaux C, Baldet P, Joubsès J, Dieuaide-Noubhani M, Just D, Chevalier C, Raymond P (2003) Physiological, biochemical and molecular analysis of sugar-starvation responses in tomato roots. J Exp Bot 54:1143-1151

Duranti M, Consonni A, Magni C, Sessa F, Scarafoni A (2008) The major proteins of lupin seed: characterisation and molecular properties for use as functional and nutraceutical ingredients. Trends Food Sci Tech 19:624-633

Eastmond PJ, Graham IA (2001) Re-examining the role of the glyoxylate cycle in oilseeds. Trends Pl Sci 6:72-77

Eastmond PJ, Germain V, Lange PR, Bryce JH, Smith SM, Graham IA (2000) Postgerminative growth and lipid catabolism in oilseeds lacking the glyoxylate cycle. Proc Natl Acad Sci USA 97:5669-5674

Graham IA (2008) Seed storage oil mobilization. Annu Rev Plant Biol 59:115-142

Graham IA, Derby KJ, Leaver CJ (1994) Carbon catabolite repression regulates glyoxylate cycle gene expression in cucumber. Plant Cell 6:761-772

Hayashi M, De Bellis L, Alpi A, Nishimura M (1995) Cytosolic aconitase participates in the glyoxylate cycle in etiolated pumpkin cotyledons. Plant Cell Physiol 36:669-680

Heller R (1954) Recherches sur la nutrition minérale des tissus végétaux ciltivés in vitro. Ann Sci Nat Bot Biol Veg 14:1-223

Hooks MA, Turner JE, Murphy EC, Graham IA (2004) Acetate nonutilizing mutants of Arabidopsis: evidence that organic acids influence carbohydrate perception in germinating seedlings. Mol Gen Genomics 271:249-256

Hooks MA, Turner JE, Murphy EC, Johnston KA, Burr S, Jarosławski S (2007) The Arabidopsis ALDP protein homologue COMATOSE is instrumental in peroxisomal acetate metabolism. Biochem J 406:399-406

Karnowsky MJ (1965) A formaldehyde-glutaraldehyde fixative of high osmolarity for use in electron microscopy. J Cell Biol 27:137-138 
Kaur N, Reumann S, Hu J (2009) Peroxisome biogenesis and function. The Arabidopsis book. American Society of Plant Biologists, Rockville. doi:10.1199/tab.0123. http://www.aspb. org/publications/arabidopsis/

Koch KE (1996) Carbohydrate-modulated gene expression in plants. Annu Rev Plant Physiol Plant Mol Biol 47:509-540

Kunze M, Pracharoenwattana I, Smith SM, Hartig A (2006) A central role for the peroxisomal membrane in glyoxylate cycle function. Biochim Biophys Acta 1763:1441-1452

Lehmann T, Ratajczak L (2008) The pivotal role of glutamate dehydrogenase $(\mathrm{GDH})$ in the mobilization of $\mathrm{N}$ and $\mathrm{C}$ from storage material to asparagine in germinating seeds of yellow lupine. J Plant Physiol 165:149-158

Lehmann T, Ratajczak L, Deckert J, Przybylska M (2003) The modifying effect of sucrose on glutamate dehydrogenase (GDH) activity in lupine embryos treated with inhibitors of RNA and protein synthesis. Acta Physiol Plant 25:325-335

Lehmann T, Skrok A, Dabert M (2010) Stress-induced changes in glutamate dehydrogenase activity imply its role in adaptation to $\mathrm{C}$ and $\mathrm{N}$ metabolism in lupine embryos. Physiol Plant 138:35-47

Lundgren Rose T, Bonneau L, Der C, Marty-Mazars D, Marty F (2006) Starvation-induced expression of autophagy-related genes in Arabidopsis. Biol Cell 98:53-67

Marty F (1999) Plant vacuoles. Plant Cell 11:587-599

Masclaux-Daubresse C, Reisdorf-Cren M, Pageau K, Lelandais M, Grandjean O, Kronenberger J, Valadier MH, Feraud M, Jouglet T, Suzuki A (2006) Glutamine synthetase-glutamate synthase pathway and glutamate dehydrogenase play distinct roles in the sink-source nitrogen cycle in tobacco. Plant Physiol 140:444-456

Miller GW (1993) The effect of fluoride on higher plants. Fluoride 26:3-22

Nyathi Y, Baker A (2006) Plant peroxisomes as a source of signalling molecules. Biochim Biophys Acta 1763:1478-1495

Palomo J, Gallardo F, Suarez MF, Canovas FM (1998) Purification and characterization of $\mathrm{NADP}^{+}$-linked isocitrate dehydrogenase from Scots pine-evidence for different physiological roles of the enzyme in primary development. Plant Physiol 118:617-626

Penfield S, Rylott EL, Gilday AD, Graham S, Larson TR, Graham IA (2004) Reserve mobilization in the Arabidopsis endosperm fuels hypocotyl elongation in the dark, is independent of abscisic acid, and requires PHOSPHOENOLPYRUVATE CARBOXYKINASE1. Plant Cell 16:2705-2718

Penfield S, Graham S, Graham IA (2005) Storage reserve mobilization in germinating oilseeds: Arabidopsis as a model system. Biochem Soc Trans 33:380-383

Penfield S, Pinfield-Wells HM, Graham IA (2006) Storage reserve mobilisation and seedling establishment in Arabidopsis. The Arabidopsis book. American Society of Plant Biologists,
Rockville. doi:10.1199/tab.0100. http://www.aspb.org/ publications/arabidopsis/

Poirier Y, Antonenkov VD, Glumoff T, Hiltunen JK (2006) Peroxisomal $\beta$-oxidation-A metabolic pathway with multiple functions. Biochim Biophys Acta 1763:1413-1426

Pracharoenwattana I, Smith SM (2008) When is a peroxisome not a peroxisome? Trends Pl Sci 13:522-525

Pracharoenwattana I, Cornah JE, Smith SM (2005) Arabidopsis peroxisomal citrate synthase is required for fatty acid respiration and seed germination. Plant Cell 17:2037-2048

Pracharoenwattana I, Cornah JE, Smith SM (2007) Arabidopsis peroxisomal malate dehydrogenase functions in $\beta$-oxidation but not in the glyoxylate cycle. Plant J 50:381-390

Qin J, Chai G, Brewer JM, Lovelace LL, Lebioda L (2006) Fluoride inhibition of enolase: crystal structure and thermodynamics. Biochemistry 45:793-800

Quettier AL, Eastmond PJ (2009) Storage oil hydrolysis during early seedling growth. Plant Physiol Biochem 47:485-490

Ramon M, Rolland F, Sheen J (2008) Sugar sensing and signaling. The Arabidopsis book. American Society of Plant Biologists, Rockville. doi:10.1199/tab.0117, http://www.aspb.org/ publications/arabidopsis/

Ratajczak W, Lehmann T, Polcyn W, Ratajczak L (1996) Metabolism of amino acids in germinating yellow lupin seeds. I. The decomposition of ${ }^{14} \mathrm{C}$-aspartate and ${ }^{14} \mathrm{C}$-glutamate during the imbibition. Acta Physiol Plant 18:13-18

Ratajczak W, Polcyn W, Lehmann T, Ratajczak L (1998) Changes in the activity of phosphoenolpyruvate carboxylating enzymes in germinating yellow lupin seeds. Acta Physiol Plant 20:119-122

Reddy MP, Kaur M (2008) Sodium fluoride induced growth and metabolic changes in Salicornia brachiata Roxb. Water Air Soil Pollut 188:171-179

Rolland F, Baena-Gonzalez E, Sheen J (2006) Sugar sensing and signaling in plants: conserved and novel mechanisms. Annu Rev Plant Biol 57:675-709

Spurr AR (1969) A low viscosity epoxy resin embedding medium for electron microscopy. J Ultrastruct Res 26:31-43

Thompson A, Vierstra R (2005) Autophagic recycling: lessons from yeast help define the process in plants. Curr Opin Pl Biol 8:165-173

To JPC, Reiter WD, Gibson SI (2002) Mobilization of seed storage lipid by Arabidopsis seedlings is retarded in the presence of exogenous sugars. BMC Plant Biol 2:4

Turner JE, Greville K, Murphy EC, Hooks MA (2005) Characterization of Arabidopsis fluoroacetate-resistant mutants reveals the principal mechanism of acetate activation for entry into the glyoxylate cycle. J Biol Chem 280:2780-2787

Yu SM (1999) Cellular and genetic responses of plants to sugar starvation. Plant Physiol 121:687-693 